Education for Information, 19 (1), March 2001, 3-18 [ISSN 0167-8329] [online]:

http://iospress.metapress.com/media/afplyjmhvqug7aylwa7w/contributions/r/t/n/y/rtny7uyl79eetgrf.pdf

[Accessed 26 June 2008] ; also reprinted in error in 19 (2), June 2001.

\title{
MANAGEMENT EDUCATION IN LATIN AMERICA AND THE CARIBBEAN
}

\author{
Ian M. Johnson
}

The Robert Gordon University, Aberdeen, Great Britain (i.m.johnson@rgu.ac.uk)

Aurelia Fuertes Medina

Pontificia Universidad Catolica del Peru, Lima, Peru (afuerte@pucp.edu.pe)

Luis A. Herrera

Planta Piloto de Inginieria Quimica, Bahia Blanca, Argentina (biherrer@criba.edu.ar)

\begin{abstract}
This paper examines some issues relating to the development in Latin America and the Caribbean of the managerial expertise that underpins the modernisation of library and information services. It reports on part of a joint IFLA/FID project, principally funded by the UNESCO Participation Programme, and reviews results from two surveys. One obtained responses from Schools of Librarianship and Information Sciences in the region, providing data on the priorities they attach to elements of their management curriculum, and teaching methods. The other gathered data from employers on their awareness of modern management techniques, their management development needs and approaches, and their perceptions of the management education available. The results of the two surveys are compared and considered, and some proposals are made for addressing issues raised. Whilst the Schools appear to be meeting the employers' key requirements, there is still some degree of mismatch between employers' expectations and Schools' priorities, but the Schools are open to change and a constructive dialogue is advocated. It is also suggested that more attention needs to be given to staff development and to the provision of supporting continuing education programmes to raise the level of management knowledge and expertise, and that the international organisations should consider encouraging the production and exchange of teaching materials. A major challenge for the Schools will be to overcome the traditionally rigid disciplinary boundaries within the Universities to collaborate on new course developments.
\end{abstract}

\section{Introduction}

Management has long been seen as a key element in the work of the librarian and information specialist. For many years the curricular model for the Schools of Librarianship and Information Sciences ${ }^{1}$ was based on the assumption that graduates would need the skills appropriate to working in large library organisations. However, it is increasingly recognised in the industrialised countries that a growing proportion of graduates now take their first job 
in organisations where they are the sole information professional, where they may be called on to undertake a wide range of information-based tasks, and where their success depends as much on their managerial ability, personal qualities, and 'political' ability as on their professional skills. This has, of course, always been a significant feature of professional practice in countries where library and information services are less well developed, as is the case in much of Latin America and the Caribbean. Attention has also begun to be given to the fundamental role that information plays in the management of any organisation ${ }^{2}$, and the need for information professionals to have a broader appreciation of the managerial contexts in which information is applied. ${ }^{3}$

As a result of the changing occupational environment, the focus of teaching has shifted in the last 30 years from discussing the administrative tasks carried out as part of the operation of libraries to creating an understanding of the applications of modern management theories. Rehman, for example, examined the development of management education in the Schools of Librarianship in the United States in the mid 1980s, discussing the development of the curriculum, its strengths and alleged shortcomings, and the way in which faculty were qualified to teach the subject. ${ }^{4}$ Johnson et al. outlined how, in Britain in the 1990s, not only were the students in the Schools of Librarianship given a good grounding in basic management theory and practice, but there was also extensive provision for continuing education through intensive management development programmes for senior professionals, and an extensive range of short courses on management topics. ${ }^{5}$

There was some evidence in the literature of the application of modern management techniques in the region, for example, in the field of financial management ${ }^{6}$, and Total Quality Management. ${ }^{7}$ There is also a small but growing body of literature produced in Latin America on education for library and information management. Much of this is produced in Spanish or Portuguese in the 60 or so journals published in the region. A search on INFOBILA ${ }^{\mathrm{i}}$ using the outmoded term 'administracion' and the more contemporary terms 'gestion' and 'gerencia' identified a number of papers on related themes. Approaches to teaching the core subjects of contemporary management education appear to have been rarely discussed. More commonly found are discussions of teaching new programmes in 'Information Management' and 'Information Resources Management', with their greater emphasis on managing information technology and systems.

\section{Surveys}

The need to include management in the curriculum has been given regular consideration in the literature in the region ${ }^{8}$, particularly in Brazil. ${ }^{9,10,11}$ However, a study carried out by Marques in Brazil in 1995/96 suggested that the needs of the directors of libraries and information centres for recruits with management skills were still not being met by the Schools of Librarianship. ${ }^{12}$

At around the same time, and perhaps in part prompted by Marques' study, feedback from members of the International Federation of Library Associations (IFLA) suggested that management education and management practice in the region had not kept pace with

\footnotetext{
${ }^{\mathrm{i}}$ A database of abstracts of Latin American publications in the field of Librarianship and Information Sciences, produced since 1985 by the National University of Mexico's Centre for Research in Librarianship (UNAMCUIB) in collaboration with partner Universities in 8 other countries, and freely searchable on its Web site, viewed on 02 October 2008 at URL - http://cuib.unam.mx/infobila/index.html
} 
developments in other parts of the world. Among the recommendations made by the participants in a meeting organised by IFLA in 1987 had been one that identified management teaching as an area in need of improvement ${ }^{13}$, and the IFLA Section on Education and Training had subsequently published some guidelines for teaching management. ${ }^{14}$ In the light of the feedback from the region, plans were made for a workshop to discuss problems and identify solutions, preceded by 2 small surveys. The intention was to provide a basis for stimulating discussions at a workshop rather than to conduct a rigorous exercise in gathering empirical data. This paper brings together part of the results of those surveys, and makes some comparisons between the practices and opinions of the teachers and the employers. The surveys contributed to useful discussions at the workshop, which was held in Valparaiso in April $1998^{15}$, and some further reflections on the issues raised there. ${ }^{16}$

One questionnaire was sent to the Heads of the 58 Schools identified as existing in the 26 countries in the region. Whilst rather more than half the total number of Schools of Librarianship and Information Science in the region can be found in Brazil and Argentina, in most countries there are only one or 2 Schools, and there are 9 countries where there appears to be no School. Altogether 30 completed replies were received, a response rate of a little over $50 \%$, including responses from 12 of the 17 countries where Schools were known to exist. ${ }^{17}$ Although their situations differ widely, the academic environment appears generally rather more challenged by structural and resource problems compared with industrialised countries. ${ }^{18}$

A small survey of managers of library and information services was also carried out, using a questionnaire covering a similar range of topics. The questionnaire was sent to IFLA institutional and personal ${ }^{\mathrm{ii}}$ members in the region, and to a representative, but by no means comprehensive list of University libraries, "often the best endowed in terms of budget, professional staff and technological infrastructure.” 19 Altogether 137 questionnaires were mailed to 26 countries. By the time the analysis was made, 39 questionnaires had been completed and returned from 15 countries. The mailing and the responses could not be considered to be a representative sample of the different types of library and information services, nor was the sample a reflection of the relative number of units in each country. The overall response rate (28\%) was poor, but possibly predictably so in the context of an international survey. Whilst these results may not permit firm conclusions to be drawn, the responses do provide some insights into the issues raised and are sufficiently interesting to justify comment. $^{20}$

\section{Expectations of management development}

To assess the extent that the management development was considered necessary, the attitudes of both employers and teachers were examined with the aim of revealing the importance that should be attached to related knowledge and skills. The approach chosen was to make an evaluation based on their overall approach to priorities for course design and management development. They were asked to indicate the priority assigned to six fundamental aspects of management: management of services, financial management, management of people, management of technologies, management of organisations, and management of change.

\footnotetext{
${ }^{\text {ii }}$ In many developing countries, individuals tend to be IFLA members rather than institutions, because the personal subscription rate is lower and/or because of the need to reconcile institutional priorities and limited budgets. Questionnaires were not sent to IFLA member associations.
} 
Whilst most Schools considered it very necessary to develop the knowledge and skills required to enable their students to manage the services provided by libraries and information units, a similarly substantial proportion acknowledged the necessity of teaching them to manage technologies. Fewer than half considered it very necessary to teach them how to manage change, people, or organisations. Teaching financial management was not considered a first priority in many Schools, but featured more strongly in their secondary priorities.

In absolute terms, the employers' highest priority was attached to developing competencies in managing information technologies. Few attached particularly high priority to developing management skills other than the management of services and the management of the change. Interestingly, although managing people was the top priority for few employers, many more placed it as their principal secondary concern. The results suggested that the employers appeared to consider managing finances as something with which their staff are not involved to any great extent.

In overall terms, then, there appeared to be little difference between the employers' needs and expectations and what the Schools seek to emphasise in their teaching. This is an encouraging basis for any future dialogue between the 2 groups. To facilitate that dialogue, the surveys then sought to establish in more detail which are the skills that are considered more important within each aspect of management, and respondents were asked to indicate the emphasis they felt should be put on the development of certain skills relevant to each area of management, drawn from the IFLA guidelines. ${ }^{21}$

\section{Managing services}

\begin{tabular}{|l|c|c|}
\hline & Employers & Schools \\
\hline Ability to identify key objectives and formulate plans & 1 & 2 \\
\hline Ability to analyse user needs & 2 & 1 \\
\hline Knowing how to set priorities & 3 & 3 \\
\hline Ability to analyse and interpret management information & 4 & 9 \\
\hline Ability to effectively manage cooperative efforts & 5 & 6 \\
\hline Knowing how to enhance and measure impact & 6 & 8 \\
\hline Ability to set up procedures for service delivery & 7 & 5 \\
\hline $\begin{array}{l}\text { Ability to write effective reports and make effective presentations } \\
\text { about results }\end{array}$ & 8 & 7 \\
\hline Familiarity with marketing techniques & 9 & 4 \\
\hline
\end{tabular}

Table 1. Ranking of importance attached to aspects of managing services

Employers and Heads of Schools were asked which competencies they considered to be most important in managing library and information services. An emphasis on planning, prioritising, and evaluating results is noticeable in the employers' responses. The employers' priorities had generally been recognised by the Schools. There were, however, significant differences between the employers' expectations in two aspects of management of services and the priorities attached by the Schools to teaching them. It can be seen that whilst using management information was the $4^{\text {th }}$ highest priority for the employers, it was rated the lowest priority by the Schools, who also assigned a lower priority to measuring services' impact. 
This seeming lack of emphasis is important to note, as it may signify a lack of concern for teaching modern scientific management methods.

Most Schools also gave a much higher priority to teaching marketing than the employers seemed to require. It is not clear whether the employers understood 'marketing' in its broadest sense, from analysing needs to promoting desires. If it was seen in its broad sense, the emphasis on analysing user needs is in marked contrast to the demand for the marketing expertise. If it is believed to refer only to promotional activities, it may reflect some concern to avoid stimulating demands that cannot be met.

\section{Managing finances}

\begin{tabular}{|l|c|c|}
\hline & Employers & Schools \\
\hline $\begin{array}{l}\text { Knowing how to prepare a good argument to obtain adequate } \\
\text { funding }\end{array}$ & 1 & 1 \\
\hline Knowing how to generate income for the service & 2 & 3 \\
\hline Ability to allocate money to a variety of activities & 4 & 5 \\
\hline Knowing how to cost services and products & 5 & 2 \\
\hline Ability to understand and utilise numeric data & 6 & 4 \\
\hline Ability to monitor expenditure & 4 \\
\hline
\end{tabular}

Table 2. Ranking of importance attached to aspects of financial management

The employers' emphasis on knowing how to secure better budgets clearly reflects the concern of service managers faced with demands they cannot meet. Again, the Schools have recognised the employers' highest priority for underpinning knowledge and skills, but their views on the priorities to be attached to teaching other aspects of financial management are at variance with those of the employers. This was perhaps explained by the fact that, in absolute terms, the concept of generating income to supplement the organisational budget and attention to other aspects of managing finances do not yet appear to feature as strong priorities for employers or teachers. In such circumstances, a consensus on what is important is unlikely to emerge.

The results seemed to point to a slower evolution in approaches to the development of skills in managing budgets compared with the professional situation in Europe and North America. There was a marked contrast between the importance given to obtaining funds and the lesser interest in developing other financial skills equally or more necessary to demonstrate how library and information services deliver value for money in a complex and competitive organisational context.

\section{Managing people}

\begin{tabular}{|l|c|c|}
\hline & Employers & Schools \\
\hline Ability to take difficult decisions & 1 & 5 \\
\hline Ability to motivate staff & 2 & 2 \\
\hline Ability to plan and execute training and development activities & 3 & 4 \\
\hline Ability to build effective teams & 4 & 6 \\
\hline Ability to identify future staffing needs & 5 & 7 \\
\hline
\end{tabular}




\begin{tabular}{|l|l|l|} 
Ability to manage cooperation with other institutions & 6 & 8 \\
\hline Ability to select suitable staff & 7 & 1 \\
\hline Ability to allocate appropriate work & 8 & 3 \\
\hline Ability to negotiate effectively & 9 & 9 \\
\hline
\end{tabular}

Table 3. Ranking of importance attached to aspects of human resource management

Managing people was seen as the lowest of the employers' overall priorities for developing the expertise of their staff. It was interesting, therefore, to note the emphasis they placed on taking difficult decisions. This suggests that they are conscious of the need for care in deploying the limited human resources at their disposal. Some insights into the nature of these decisions can be seen in the highest second ranking priorities - allocating work and negotiating effectively. Managing people is clearly no easier in the region than it is elsewhere.

There are some noticeable differences between the employers' perceived needs and the priorities the Schools attach to teaching various aspects of the topic, particularly in respect of selecting staff and allocating appropriate work. This suggests that whilst there may be no strong tradition of delegating these responsibilities in practice, these are practical aspects that the staff of the Schools feel able to simulate in their teaching. Indeed, the Schools' priorities appear generally to be driven, understandably, by similar considerations or by the existence of a widely recognised body of theory, for example in motivation.

\section{Managing technologies}

\begin{tabular}{|l|c|c|}
\hline & Employers & Schools \\
\hline Ability to plan and implement new processes & 1 & 2 \\
\hline Ability to interpret legal and ethical issues to users & 2 & 3 \\
\hline Ability to specify suitable equipment and services & 3 & 1 \\
\hline
\end{tabular}

Table 4. Ranking of importance attached to aspects of managing technology

The high priority attached by employers to training in managing change is emphasised in the emphasis placed on skills in managing technology. Planning and implementing new processes is clearly a widespread challenge in the region, although it might seem reasonable to expect that there has been an improvement since McCarthy's (1983) study of library automation in Brazil showed that information was transferred between institutions in an almost random manner. ${ }^{22}$

Technology has forced itself onto the managerial and educational agendas, and most Schools appear to have made an effort to provide the underpinning knowledge and skills required by the employers. Although a few Schools still appear to ignore the development of these skills, the majority clearly considered it important to develop their students' ability to select technical equipment and services and plan and implement new processes. However, markedly fewer appear to have recognised the need to teach about the legal and ethical aspects of information work, to which technology - and the Internet in particular - have brought a fresh emphasis. It may be their view of their students' likely career development and future needs that motivates them to focus more on teaching aspects of specifying equipment and services than on the legal and ethical issues. It may also be because they are 
reluctant to teach in an area without adequate guidelines. However, some guidelines are now emerging from UNESCO ${ }^{\text {iii }}$ and the international non-governmental agencies ${ }^{23}$, and a range of international case studies can be tracked through the weekly UNESCO Observatory email service. ${ }^{\text {iv }}$

Modern management techniques

\begin{tabular}{|l|c|c|c|}
\hline & \multicolumn{2}{|l|}{ Employers } & Schools \\
\hline & Familiar & Valued & Teach \\
\hline & $\%$ & $\%$ & $\%$ \\
\hline Total Quality Management & 59 & 44 & 83 \\
\hline Marketing techniques & 59 & 21 & 90 \\
\hline Mission statements & 54 & 49 & 80 \\
\hline Process Re-engineering & 54 & 31 & 70 \\
\hline Performance management & 44 & 36 & 57 \\
\hline Value chain analysis & 31 & 15 & 50 \\
\hline Benchmarking & 28 & 10 & 40 \\
\hline Stake holding & 15 & 5 & 0 \\
\hline
\end{tabular}

Table 5. Awareness and perceived usefulness of management techniques, and their inclusion in the curriculum

Eight management techniques that could be included as part of a contemporary education or training in management were examined to determine whether employers were aware of them, and thought them useful, and the extent to which the Schools' mentioned them in their teaching. These were drawn from a list of techniques that had had been promoted over the last decade, and which had been the subject of recent global research. ${ }^{24}$

The majority of employers were aware of older management techniques such as Total Quality Management and marketing. Nevertheless, the responses demonstrated a lack of widespread familiarity with some management techniques, particularly the more recently promoted approaches. Those who were familiar with particular techniques were asked their opinion of the usefulness of each of them in managing library and information services. Generally, it appears that these techniques were felt to be useful by those acquainted with them.

The limited importance attached by the employers to knowledge of marketing techniques is difficult to explain, but confirms earlier responses. Interestingly, this subject was the one that was included in the curriculum by most Schools. Marketing was the subject of a detailed manual for teachers published more than 10 years ago by UNESCO. ${ }^{25}$ This may explain the gulf referred to earlier between the expectations of the employers and the greater emphasis in the Schools' teaching. Given that the emphasis placed on teaching marketing by the Schools as a result of the encouragement of major international organisations such as UNESCO and IFLA, there appears to be a clear need for an early dialogue between the Schools and the employers about this aspect of management development.

\footnotetext{
iii Details of the INFOETHICS program were viewed on the UNESCO Web site on 02 October 2008 at URL http://www.unesco.org/webworld/infoethics/infoethics.htm

${ }^{\text {iv }}$ For further information and to subscribe to this weekly email list, visit the Web site of the UNESCO Observatory on the Information Society viewed on 02 October 2008 at URL http://www.unesco.org/webworld/observatory/index.shtml
} 
Total Quality Management and Mission statements, concepts that were at the height of fashion in the early 1990s, are included in the curriculum in some way by more of $80 \%$ of the Schools. As noted earlier, the application of TQM has been touched on within the LIS literature in the region, and it has also been discussed at a regional conference for teachers. ${ }^{26}$ More recent techniques such as Process Re-engineering and Performance Management were less well covered in the majority of Schools. Indeed, fewer than half the Schools appeared to have given any attention to the emergence of the latest techniques.

Some of the global interest in these new techniques could be ascribed to the business community's continual fascination with new ideas for improving performance when faced with short-term challenges, and they could prove to be a transient feature of the management landscape. However, libraries cannot isolate themselves from these new approaches when they are introduced into an organisation, and the Schools of Librarianship and Information Sciences have a role to play in preparing students and practitioners to respond appropriately. It is therefore perhaps encouraging that the Schools appeared rather more proactive in making their students aware of these techniques than employer opinion suggested that they needed to be. Nonetheless, it was also illuminating that attention focused on the older methods and techniques whereas the most recent trends in professional and managerial practice do not yet seem to have achieved the same receptivity. Taken together with the employers' limited awareness of the newer techniques, it suggested that perhaps these ideas had not yet been widely discussed in the region.

\section{Employers' perceptions of management education and training for librarians and information specialists}

The answers received from employers to a number of open questions about the main problems encountered in management development for library and information services were revealing. The problems they perceived can be categorised as operational and institutional. Operational problems included more or less the whole spectrum of management activity - inadequate planning, implementation and evaluation - with none being more frequently mentioned than others. Interestingly only one employer identified the lack of training and development activities as a contributing factor, and one other referred opaquely to "courses of librarianship”. In identifying the institutional problems some employers predictably emphasised issues related to the financial infrastructure of the library and information service, but more mentioned the difficulties in establishing a contemporary image of the service and adequate support within the organisation as a whole, and even more mentioned a shortage of (appropriately trained) personnel.

When the employers were asked to pass judgement on the management education provided by the Schools of library and information sciences in their country, it was encouraging that more than half of them considered it to be at least satisfactory. However, it must be a cause for concern that a quarter considered their local Schools to be poor in this respect at least.

Several claimed that the curriculum was outdated.

\begin{tabular}{|l|c|c|}
\hline & & \\
\hline Good & 4 & $10 \%$ \\
\hline Satisfactory & 20 & $51 \%$ \\
\hline Bad & 7 & $18 \%$ \\
\hline
\end{tabular}




\begin{tabular}{|l|l|l|}
\hline None exist in the country & 3 & $7 \%$ \\
\hline No response & 5 & $13 \%$ \\
\hline
\end{tabular}

Table 6. Employers' opinion of the effectiveness of current management education and training

A large number of developments were proposed. A large number of suggestions were for changes and updating in the curricula of the Schools, and pointed to a range of management topics for development. Some employers called for a greater supply of short courses for continuing education and for postgraduate courses in management in those countries where there are already Schools of Librarianship and Information Sciences, as well as for distance learning courses. Some mentioned the need for the Schools to be more involved with the national profession associations, and generally more open to the professional community. Even more mentioned the need for the teachers to be themselves better educated, more actively engaged in continuing their own education, and more exposed to realities in other countries.

A wide range of barriers to improvements in management education and training was identified by those employers responding to the survey. Some of these were probably unique to particular countries. For example, a number of comments drew attention to the lack of appropriate educational facilities in their countries, not only for librarianship but also for management development. Some employers pointed to general issues hindering change in their countries, such as the lack of a legal framework for the profession, or the absence of any structured approach to the improvement of higher education. Others attributed problems to the low visibility of the profession, or to the protectionist attitude of the members of other professions, such as doctors, lawyers, qualified managers etc., who have a greater presence and influence in the decision-making levels of society.

The traditional mentality of the Schools and the organisations that influence them also came in for criticism. Some employers claimed that there was a lack of direct relation between the courses and the tasks performed in libraries, and complained that teachers did not have current or recent work experience in libraries or information units. Others, however, placed some of the blame on the influence older practitioners who had only a limited conception of the changes taking place in the job market for information professionals and of the skills currently in demand. They claimed that few of the older practitioners have a Masters degree or $\mathrm{PhD}$, and have difficulty in accepting that the management function has to be developed at postgraduate level, through specialization and continuing education.

Some employers' comments did, however, include a broader appreciation of the economics and lack of financing of the education system in general, and an awareness that institutional resources appear to be decreasing in many cases. This was recognised as impacting not only on the rapid redundancy of the technological equipment available for teaching in the Schools, but also on their ability to pay more to recruit better teachers and to provide adequate opportunities for their retraining. There were also economic and other barriers imposed on potential students - high costs of further qualifications, the incompatibility of class times with work schedules, and the reluctance of employers, in general, to permit studying that interfered with work.

One employer noted that language barriers impact on advanced study in a field in which English is the major language used in journals and published conference proceedings on 
leading-edge topics. Another noted the lack of support of international institutions, without specifying what support was needed, or from which organisations.

\section{Teaching methods in the Schools of Librarianship}

\begin{tabular}{|l|c|c|c|c|c|}
\hline \multirow{2}{*}{ Teaching method } & \multicolumn{2}{|c|}{ Used } & \multicolumn{2}{c|}{ Not used } & TOTAL \\
\cline { 2 - 6 } & No. & $\%$ & No. & $\%$ & No. \\
\hline Specially prepared case studies & 28 & 93 & 2 & 7 & 30 \\
\hline Group exercises & 29 & 97 & 1 & 3 & 30 \\
\hline Work experience placements & 28 & 93 & 2 & 7 & 30 \\
\hline $\begin{array}{l}\text { On-site discussion of experience } \\
\text { of managing change }\end{array}$ & 22 & 73 & 8 & 27 & 30 \\
\hline
\end{tabular}

Table 7. Approaches to teaching management

To test the Schools' willingness and ability to deliver a modern curriculum, they were asked whether they used certain teaching methods commonly adopted in teaching management. In all the Schools it seems that widespread use is made of the best-known methods. These results above all confirm that the teachers do try to use a variety of approaches. This is a very commendable effort. It does nevertheless raise the question as to how the teachers acquire the information, necessary experiences, data, etc. for the preparation of these activities. Teaching practical aspects of management is not necessarily always appropriate in a University course, but a judicious mixture of theoretical underpinning, case studies, and role-playing can sensitise students to issues they are likely to face and to approaches they may need to adopt. Some inputs from employers may, however, be desirable to create the case study material necessary to impart an approximation of reality. If the teachers do not also work as managers in libraries and information service, because they are only part-time teachers or have a second job in a library, it must be assumed that in most cases there exists a good relationship with practitioners that enables the teachers to develop appropriate theoretical-practical instruments.

\section{Developing management education in the region}

Marques concluded that, in Brazil, a consensus did not exist on the ideal curriculum, and that the importance given to the subject varied from School to School. ${ }^{27}$ From this survey, it is possible to confirm that the teaching of modern management has not yet been consistently integrated into the Schools' curricula across the region. It also possible to say that Schools throughout the region are open to winds of change in terms of the introduction of new ideas and new approaches. Then, why - if the effective management of information has been widely recognised as such a fundamental part of the economic and social fabric in recent years - does there still appear to be a degree of mismatch between what the employers expect and what the Schools in the region aim to provide to develop the necessary knowledge and skills?

In the responses to these surveys, important deficiencies are suggested that can be pointed to as probable barriers to the implementation of improvements in management teaching. The perception of some employers' that management education for the LIS profession in the region is outmoded appears to be borne out in some cases by comparing the employers' needs and expectations with what the Schools are prioritising in their teaching. It cannot however, 
be assumed that the either the Schools or the employers are mistaken in their views. It must be acknowledged that there is as much a divergence of views amongst the employers on the importance of various aspects of management development as there is within the Schools. These issues can only be resolved by regular, closer, open and informed dialogue between both parties. Whilst the Schools appear to have correctly identified and responded to the employers' key requirements, they cannot be entirely absolved of blame for the current situation. It is possible to sense a great necessity for the leadership that would impel a better positioning of professional programmes. However, the employers may also have failed to take a positive and progressive role.

The inclusion in the curriculum of the management of technologies not only demonstrates that the LIS Schools can respond to a new vision of the discipline, but also provides a further lesson. In most countries, automation projects and applications of new technologies led librarians to understand that they needed to break out of certain self-imposed limits on their functions and knowledge base. As the management of library and information services becomes more complex, it must also become widely understood that a higher importance has to be assigned to the inclusion of management in the Schools' curricula. ${ }^{28}$ A further review of the specific knowledge and skills that are actually developed in the courses is needed to complement this acceptance.

The small number of students in many of the Schools at present also raises the necessity to seriously examine the future of librarianship and information sciences in the region. It would be useful to investigate what makes studying LIS attractive and what is a deterrent to the young people who will become part of the region's burgeoning pool of labour in the next millennium. The factors to consider are many, but possibly one of most important is too understand the causes of an apparent perception of the profession that it is not only unattractive but also unnecessary. This could provide a more effective focus for the debate on whether there are advantages in redefining the characteristics of the professionals who graduate from these Schools. One of the alternatives might, for example, be a shift from education in 'management of information units' to one in 'management of information' based on a deeper understanding of its value and impact. Some mature and informed reflection seems necessary on what the required professional management profile in each country really is the one for which some demand is being expressed. A precipitate response to one or two isolated indicators or forcefully expressed opinions can become in the long run more of a problem than a solution.

It will also be necessary to take account of the socio-economic conditions that encourage or constrain the growth and development of the job market and that change the demand for knowledge and skills. It is only an integrated analysis of these various factors that can assure a match between the expectations of employers and the response of the educators. This investigation suggests that, at the moment, the employers in Latin America and the Caribbean may be encountering difficulty in clearly and coherently articulating some of their needs for management development in a way that might be helpful to the Schools in the region. The reasons for this are not clear, and require further exploration.

Some of the reasons can be found within the Schools. The results of the survey point to the existence of small teams of full-time academics, themselves not necessarily well educated in professional or managerial terms, with the implication therefore of a limited potential - in terms of the operational capacity in certain Schools - to independently develop sophisticated and progressive programmes. ${ }^{29}$ The absence of up-to-date postgraduate programmes in the region causes these problems to be magnified, since both teaching and employing institutions 
consequently lack sufficient highly educated professionals with relevant experience and a broad vision to provide the necessary leadership. There does not appear much evidence of relevant study at a postgraduate level combining librarianship or information sciences with management studies being undertaken by academics, nor by practitioners.

Although the great majority of Schools in the region have already incorporated widely recognised and established management techniques in their curricula, the development of a solid understanding of management, continually updated, and integrated throughout the curriculum depends on many more factors than the single decision to include it. It also requires appropriately knowledgeable, skilled, and enthusiastic teachers to do it. This does not depend only on the level of the teachers' own educational studies, but also on their academic discipline, and, in the case of management, on maintaining close contact with professional practice. There is a danger that if the development of aspects of management in the educational programmes is mainly in the hands of the full-time teachers of LIS, the treatment will be academically sound, but may be somewhat distant from the real problems of libraries and information services, and for that reason, not necessarily lend itself to practical applications. On the other hand, practitioners with current experience of library and information service management may not necessarily be good teachers. Equally, academics who specialise in teaching management may not be able, or willing, to orient their material to the needs and contexts of the LIS community. The way forward appears to be to look for a consolidation of teaching teams of full-time academics within the LIS schools, as they are probably the ones who most appreciate the LIS context and can make a continuous contribution, and then to ensure that there are appropriate means in place to support their own continuing development. The lack of systematic provision for staff development identified by the surveys, and the limited opportunities for continuing professional development in the region, are issues that must be addressed. The two issues are inseparable.

It is also pertinent to ask why there still appears to be little specialist teaching material distributed or interchanged between the Schools in the region. There has already been much effort put into the preparation of relevant cases and exercises, according to the indications of the teaching methods in use, but maximum benefit has yet to be derived from these activities. This is no more a problem in Latin America than in other parts of the world, but emphasises the need for the international organisations to provide the necessary stimulus to encourage and perhaps sponsor the publication and exchange within the region of the materials available to assist teachers in the field.

During the last two decades, many Schools of Librarianship and Information Sciences have closed their doors, even in countries with a long and solid tradition of library education such as the United States. The cause was not necessarily just limited resources and financial problems, but often a failure to adapt educational provision well to emerging new professional profiles. This lesson does not appear to have been fully appreciated or acted upon in Latin America. A contributory problem may be the location of this speciality within the Universities. Generally, because of the origins and traditional associations of the discipline of Librarianship, the Schools in the region appear to be located in Faculties of Arts and Humanities. Beyond any discussion on the connotation of the Humanities, it remains a fact that it is difficult to establish courses to underpin new professional profiles given the rigid boundaries that traditionally exist within the Universities in the region, inhibiting the collaboration between disciplines that is essential in modern information science programmes. A particular challenge for teachers in the region will be to find ways to overcome these barriers to develop the interdisciplinary courses that are necessary in management and other fields of professional activity. 
These surveys showed that there is some scope for optimism about the future of management education in the Schools in the region, as well as indicating some problems that need to be addressed. They have pointed to the need to extend the dialogue that takes place about course development beyond the boundaries of each individual School to encompass the employers of their graduates, and also their own University authorities and their colleagues teaching the same subject in other institutions. Some further reflection is needed on how those dialogues can be initiated and brought to effective conclusions. It was also implicit in the responses that the international organisations can be influential in stimulating or supporting development, although they are not necessarily perceived as a primary source of advice or assistance, perhaps because their potential role is not clear. Some further consideration is needed on their part as to what role they might effectively play, how they can make potential beneficiaries aware of that, and what they need to do to equip themselves to undertake it.

(C)

The authors, September 2000

\section{AUTHORS}

Ian Johnson is Head of the School of Information and Media at The Robert Gordon University, Aberdeen, Scotland. He was Chairman of the International Federation of Library Associations and Institutions (IFLA) Section on Education and Training from 1991 to 1993, and Chairman of the Professional Board of IFLA from 1993 to 1995. He is currently Chairman of the Executive Board of EUCLID: the European Association for Library and Information Education and Research.

Aurelia Fuertes is the former Coordinadora of the Especialidad de Bibliotecologia y Ciencia de la Informacion, Facultad de Letras y Ciencias Humanas, Pontificia Universidad Catolica del Peru in Lima.

Luis Herrera is Director of Servicios de Informacion y Documentacion, Planta Piloto de Inginieria Quimica, CONICET - Universidad Nacional del Sur, Bahia Blanca, Argentina.

\section{REFERENCES}

\footnotetext{
${ }^{1}$ WASSERMAN, Paul. L'enseignement de la gestion en tant que matiere dans la formation des bibliothecaires, documentalistes, archivistes et autres specialistes de l'information. 1984. Paris: UNESCO. (Colloque international sur l'harmonisation des programmes. UNESCO, Paris 8-12 October, 1984.)

${ }^{2}$ KOENIG, M.E.D. Information driven management: concepts and themes - a toolkit for librarians. 1998. Munich: K.G. Saur. (IFLA Professional Series)

${ }^{3}$ MARCELLA, R.C. The development of a new Postgraduate Diploma/MSc course in Information Analysis at The Robert Gordon University in New worlds in information and documentation: proceedings of the forty-sixth FID Conference and Congress held in Madrid, Spain, 22-29 October 1992. 1994. Amsterdam: Elsevier. pp. 471-477.

${ }^{4}$ REHMAN, S.u. Management theory and library education. 1987. New York: Greenwood Press.

${ }^{5}$ JOHNSON, I.M., and others. Management education and training for librarians in Scotland. IFLA Journal, 19 (3), 1993, 280-291

${ }^{6}$ RUIZ RODRIGUEZ, M, and others. Gerencia financiera para los productos y servicios de informacion electronica [Financial management for electronic information products and services] in Congreso Norte-Sur de
} 
Informacion, ONLINE 93: sistemas, redes y tecnologia. Memorias (1, 1993, Mexico). CRUZ RAMOS, R., and ZETTER LEAL, J., comp. 1993. Mexico: UNAM, CICH, Learned Information. pp. 464-468

${ }^{7}$ SUTER, T. Calidad Total y TQM en servicios de informacion. [Total quality and TQM in information services.] Grebyd Noticias, 5 (2-3), 1994, 2-9

${ }^{8}$ FERREIRA, M.L.A.G., and others. Curriculo minimo de biblioteconomia. [Minimum curriculum for librarianship.] Revista da Escola Biblioteconomia da UFMG, 6 (1), March 1977, 92-99

${ }_{9}^{9}$ POLKE, A.M.A. Relatorio dos seminarios do curso de metodologia do ensino em biblioteconomia. [Report of seminars held during the course on teaching methodology in librarianship.] Revista da Escola Biblioteconomia da UFMG, 7 (1), March 1978, 149-200

${ }^{10}$ MIRANDA, A. Bibliotecas dos cursos de pos-graduacao em educacao no Brasil: estudo comparado. [A comparative study of libraries for post-graduate courses in education in Brazil.] 1977. Brasilia:

MEC/DAU/CAPES, 94p. Summarised as: Postgraduate education libraries in Brazil: a comparative study. Focus on International \& Comparative Librarianship, 9 (2) 1978, 15-17

${ }^{11}$ DE FIGUEIREDO, N.M. Recomendacoes praticas para o aperfeicoamento do servico de referencia/informacao nas bibliotecas brasileiras. [Practical recommendations for the improvement of the reference/information service in Brazilian libraries.] Revista de Biblioteconomia de Brasilia, 11 (1), JanuaryJune 1983, 35-44

${ }^{12}$ MARQUES DE OLIVEIRA, S. O ensino de administracao nas escolas de biblioteconomia no Brasil: correlacao entre o curriculo e a literatura da area. [Teaching administration in Schools of Librarianship in Brazil: the correlation between the curriculum and literature in the field.] 1996. Campinas, Brazil: Departamento de Pos-Graduacao em Biblioteconomia, Pontificia Universidade Catolica de Campinas. Unpublished typescript. $24 \mathrm{pp}$.

${ }_{13}$ JOHNSON, I.M., Editor. Harmonisation of education and training programmes for library, information and archival personnel: proceedings of an international colloquium, London, August 9 - 15, 1987. 1989. Munich: KG Saur. (2 vols.)

${ }^{14}$ TEES, M.H. Teaching management to information professionals: a practical approach - guidelines for instructors. IFLA Journal, 19 (3), 1993, 292-321

${ }^{15}$ JOHNSON, I.M. Workshop on the management and use of human resources in library and information work in Latin America, Valparaiso, Chile, 6 - 9 April 1998. FID Bulletin for Information \& Communication, 48 (2), March/April 1998, 54-59 (reprinted in IFLA Journal, 25 (1), 1999, 42-46)

${ }^{16}$ JOHNSON, I.M. Management development for libraries and information services in Latin America and the Caribbean. International Information and Library Review, 31 (4), December 1999, 225-244

${ }^{17}$ FUERTES MEDINA, A. Encuesta sobre la educacion en gestion en las escuelas de bibliotecologia y ciencia de la informacion de la region. [Survey on management education in the Schools of Librarianship and Information Science in the region: Paper presented at joint IFLA/FID Workshop on Management and use of human resources in library and information work in Latin America, Valparaiso, Chile, 6 - 9 April 1998.] Unpublished typescript. 1998. 14pp., plus 13 pp. of tables and diagrams

${ }^{18}$ JOHNSON, I.M., and FUERTES MEDINA, A. Librarianship and Information Studies in Latin America and the Caribbean. Focus on international and comparative librarianship, 31 (2), 2000, 61-70

${ }^{19}$ MORALES CAMPOS, E. Latin America and the Caribbean in LARGE, A. ed. World Information Report 1997/98. 1997. Paris: UNESCO. pp.107-123.

${ }^{20}$ HERRERA, L.A. Resultados de la encuesta dirigida a los empleadores de bibliotecas y servicios de informacion. [Results of a survey directed to employers in libraries and information services: Paper presented at joint IFLA/FID Workshop on Management and use of human resources in library and information work in Latin America, Valparaiso, Chile, 6 - 9 April 1998.] Unpublished typescript. 1998. 7pp.

${ }^{21}$ TEES, M.H. Teaching management to information professionals: a practical approach - guidelines for instructors. IFLA Journal, 19 (3), 1993, 292-321

${ }^{22}$ McCARTHY, C.M. Problems of library and information system automation in Brazil. Journal of Information Science, 7 (4-5), December 1983, 149-158

${ }^{23}$ FROEHLICH, T.J. Survey and analysis of legal and ethical issues for library and information services. 1997. Munich: K.G. Saur (IFLA Professional Series)

${ }^{24}$ INSTITUTE OF MANAGEMENT and BAIN \& Company. Managing the management tools. 1996. London: Institute of Management. Reported in “Dipping into the global managers' toolkit”. Professional Manager, November 1996, 30.

${ }^{25}$ SAVARD, R. Guidelines for the teaching of marketing in the training of librarians, documentalists, and archivists. 1988. Paris: UNESCO. ref. PGI-88/WS/1

${ }^{26}$ PONJUAN DANTE, G. La gestion de la calidad total en la educacion bibliotecologica. [Total Quality

Management in teaching librarianship.] Presented at: Encuentro de Educadores e Investigadores de Bibliotecologia, Archivologia y Ciencia de la Informacion de Iberoamerica y el Caribe \#3, 1996, Puerto Rico). 
Documento de trabajo D, presentaciones especiales num.2a. 1996. Recinto de Rio Piedras, Puerto Rico: Universidad de Puerto Rico, Escuela Graduada de Bibliotecologia y Ciencia de la Informacion. Unpublished typescript.

${ }^{27}$ MARQUES DE OLIVEIRA, S. O ensino de administracao nas escolas de biblioteconomia no Brasil: correlacao entre o curriculo e a literatura da area. [Teaching administration in Schools of Librarianship in Brazil: the correlation between the curriculum and literature in the field.] 1996. Campinas, Brazil: Departamento de Pos-Graduacao em Biblioteconomia, Pontificia Universidade Catolica de Campinas. Unpublished typescript. $24 \mathrm{pp}$.

${ }^{28}$ JOHNSON, I.M. Catching the tide: environmental pressures for an emphasis on management in the library and information sciences curriculum. Library Management, 20 (6), 1999, 317-332. Based on a paper presented at: 4th Conference of teachers and researchers in Librarianship, Archive Studies and Information Science in Latin America and the Caribbean, 20 to 24 April 1998, Maracaibo, Venezuela.

${ }^{29}$ JOHNSON, I.M., and FUERTES MEDINA, A. Librarianship and Information Studies in Latin America and the Caribbean. Focus on international and comparative librarianship, 31 (2), 2000, 61-70 